\title{
ULOGA NASTAVNIKA U STVARANJU POZITIVNE KLIME U ODELJENJU ${ }^{1}$
}

\author{
Marija Marković2 \\ Univerzitet u Nišu, Filozofski fakultet u Nišu, Departman za pedagogiju
}

Apstrakt: Profesija nastavnika u savremenoj školi podrazumeva nastojanje da se ostvare brojne uloge koje su dosta različite i kompleksne. Pored ostvarivanja obrazovnih zadataka, od savremenog nastavnika se očekuje da posebnu pažnju posveti vaspitnom aspektu rada sa učenicima. Važan institucionalni kontekst na čije stvaranje u značajnoj meri utiče sam nastavnik jeste kontekst odeljenja i socioemocionalne klime u njemu. Na klimu u odeljenju u značajnoj meri utiču individualne karakteristike nastavnika i učenika, način nastavnikovog rukovođenja odeljenjem, položaj učenika u nastavnom procesu, kvalitet međusobno uspostavljenih odnosa i drugi faktori. U radu se ukazuje na različita određenja termina koji se koriste za označavanje klime u odeljenju, kao i na karakteristike pozitivne i negativne odeljenske klime. Razmatraju se osobine nastavnika, vaspitni stil nastavnika, odnosi između nastavnika i učenika, učenika međusobno, kao i njihova povezanost sa klimom u odeljenju. Ukazuje se na povezanost određenih karakteristika klime u odeljenju i školskog postignuća učenika. Na kraju, ukazuje se na važnost razmatranja datih faktora u nastojanju da se uspostavi pozitivna odeljenska klima.

Ključne reči: odeljenska klima, nastavnik, učenici, školsko postignuće, odeljenski kontekst

\section{Uvod}

Profesija nastavnika u savremenoj školi sa sobom nosi zahtev za ostvarivanje brojnih uloga koje su dosta složene i podložne daljim promenama pod nastojanjem da se uvedu inovacije i izvrše reforme u okviru postojećeg školskog sistema. U literaturi se mogu pronaći brojni pokušaji klasifikacije uloga koje nastavnik ima u savremenoj školi. Jedna od njih je i klasifikacija koju daje Nenad Havelka (2000), koji uloge nastavnika klasifikuje u dve velike grupe - uloge koje se odnose na na-

\footnotetext{
${ }^{1}$ Pripremljeno u okviru projekta Održivost identiteta Srba $i$ nacionalnih manjina u pograničnim opštinama istočne i jugoistočne Srbije (179013), koji se realizuje na Univerzitetu u Nišu - Mašinski i Filozofski fakultet, finansiran od strane Ministarstva prosvete i nauke RS.
}

${ }^{2}$ marija.markovic@filfak.ni.ac.rs 
stavu i uloge koje se odnose na školu kao instituciju, unutar kojih razlikuje čitav niz poduloga. Između ostalog, od savremenog nastavnika se danas očekuje da posebnu pažnju pokloni aspektu stvaranja povoljne klime u odeljenju, kao osnove uspešnog vaspitno-obrazovnog rada sa učenicima.

Trebalo bi imati u vidu da se u učionici uspostavljaju kako privremeni, tako i dugotrajni odnosi između učenika i nastavnika (Avramović i Vujačić, 2010; Krneta, 1974). Osim toga, učenici u školskom odeljenju međusobno su povezani kako formalnim odnosima (samim tim što su u zajedničkom odeljenju), tako i neformalnim vezama (u koje dobrovoljno stupaju). Takođe, važna dimenzija socijalnih odnosa u odeljenju jesu i različiti oblici saradnje i/ili nesaradnje među učenicima (Avramović, 2010; Avramović i Vujačić, 2010). Kao značajni regulatori socijalnih odnosa u odeljenju navode se normativni propisi iz oblasti obrazovanja, moralne norme, lični stil nastavnika i učenika, kao i načini suočavanja sa iznenadnim, neočekivanim problemima (Avramović, 2010; Avramović i Vujačić, 2010).

Školsko odeljenje bi, zapravo, trebalo posmatrati kao kompleksan socijalni sistem u kome se ukrštaju uticaji različitih faktora: nastavnika, učenika, nastavnih sadržaja, školskih i vanškolskih organa upravljanja, raznovrsnih učeničkih organizacija, formalnih i neformalnih učeničkih grupa i sl. Imajući u vidu da svi ovi faktori deluju relativno samostalno, funkcija usmeravanja i usaglašavanja tih uticaja, u cilju ostvarivanja vaspitno-obrazovnih zadataka, u najvećoj meri pripada nastavniku (Krnjajić, 2002).

\section{Terminološka određenja pojma odeljenske klime}

Klima se u obrazovnom kontekstu definiše kao fenomen koji se odnosi na „relativno trajne karakteristike različitih tipova i nivoa organizacije (škola, razredi, odeljenja, grupe...) i njihov uticaj na ponašanje ljudi” (Đermanov, Kosanović i Isak, 2016: 420).

U literaturi je prisutno ukazivanje na razlike između termina školska klima i termina odeljenska klima (Avramović, 2010; Avramović i Vujačić, 2010; Đermanov, i sar., 2016; Krnjajić, 2007). Školska klima predstavlja kontekst koji ima uticaja na klimu u odeljenju, a koji obuhvata način organizacije, upravljanja i funkcionisanja škole i reflektuje se na rad nastavnika (Avramović, 2010). Nasuprot njoj, odeljenska klima se opisuje kao za svako školsko odeljenje jedinstveni i relativno trajni kvalitet interakcijsko-komunikacijskih odnosa i uticaja, koji se međusobno prožimaju i utiču na aktivnost, zalaganje i individualno ponašanje nastavnika i učenika (Đermanov i Isak, 2016).

Odeljenska klima definiše se i kao ,produkt aktivnosti nastavnika i učenika u ispunjavanju vaspitno-obrazovnih ciljeva, načina realizacije kurikuluma i stilova povezivanja članova razredne zajednice" (Krnjajić, 2007: 36). Odnosno, određuje se kao unutrašnji, relativno trajni kvalitet „ukupnih socijalnih odnosa i međusobnih uticaja u školskom odeljenju, čiji se doživljaj manifestuje na individualno ponašanje, aktivnost i zalaganje učenika i nastavnika, njihovo zadovoljstvo nastavom i ostva- 
rivanje kognitivnih, afektivnih i socijalnih ishoda vaspitnog procesa" (Đermanov i Isak, 2016: 65).

Termin odeljenska klima se u stručnoj literaturi koristi uporedo sa drugim terminima poput termina razredna klima, socioemocionalna klima, školska klima, pedagoška klima, nastavna klima, klima učenja, sredina, pedagoška atmosfera, ambijent, okruženje, ozračje, ton itd., što ukazuje na preplitanje ovih fenomena, kao i na različita shvatanja sadržaja datih pojmova. U tom kontekstu, moguće je razlikovati tri značenja pojma odeljenska klima: 1) shvatanje klime kao ukupne pedagoške atmosfere, koje se odnosi na emocionalni aspekt klime, 2) shvatanje klime u kome se u prvi plan ističu postojeće orijentacije $i$ vrednosti koje uslovljavaju međusobne odnose, i 3) shvatanje klime kao zajednički konstruisane učeničke stvarnosti, u kojoj se klima shvata kao individualni i kao grupni fenomen. Danas je dominantno treće stanovište, dok se prvo smatra prevaziđenim (Đermanov i Isak, 2016).

U literaturi je, takođe, prisutna i pojmovna razlika između termina emocionalna i socijalna klima u odeljenju (Avramović, 2010; Avramović i Vujačić, 2010; Bognar i Matijević, 2005). Emocionalna klima u odeljenju predstavlja afektivni odnos između nastavnika i učenika (osećaj vlastite vrednosti, samopoštovanje, slika o sebi, osećaj ugodnosti ili neugodnosti, sigurnosti i nesigurnosti, slobode i neslobode, straha i simpatije, ljubavi i mržnje, dosade i oduševljenja). Emocionalna klima se odnosi na afektivni ton u odnosima između nastavnika i učenika, kao i u odnosima između učenika i nastavnika, koji, zapravo, predstavlja posledicu uspostavljenih interakcija (Bratanić, 1990). Nasuprot tome, socijalna klima u odeljenju se prevashodno vezuje za socijalne odnose između nastavnika i učenika (saradnju, sukobe, moć, neformalno grupisanje), ali i za kvalitet odnosa koji dete uspostavlja u porodici, kao i kvalitet odnosa nastavnika i roditelja - imajući u vidu da dati odnosi vrlo intenzivno utiču na vaspitno-obrazovni proces (Bognar i Matijević, 2005).

U literaturi se navode odlike tzv. pozitivne (povoljne, podsticajne) klime, naspram negativne (nepovoljnoj) klime (Avramović, 2010; Avramović i Vujačić, 2010; Bognar i Matijević, 2005; Đermanov, i sar., 2016; Jelavić, 2008; Lalić, 2005). Pozitivnu klimu u odeljenju odlikuje dominacija osećaja sigurnosti i prihvaćenosti, uspešna međusobna komunikacija, međusobno poverenje, razumevanje perspektive drugog, kooperativnost, socijalna odgovornost, tolerantnost, uvažavanje različitosti i sl. Nasuprot pozitivnoj, negativnu klimu u odeljenju karakteriše otpor i nezadovoljstvo kod nastavnika i učenika, međusobno sukobljavanje, odsustvo saradnje, osećaj neslobode, neshvaćenosti, poslušnost, velika distanca na relaciji nastavnik-učenik, nepoverenje prema nastavniku, napetost, dosada, dominacija straha od neuspeha, često izostajanje s nastave itd. Kao faktori od kojih zavisi da li će u odeljenju preovladavati pozitivna ili negativna klima posebno se izdvajaju: karakteristike nastavnika, osobine učenika, odnosi između nastavnika i učenika, odnosi između učenika, nastavnikovo razumevanje ponašanja učenika, vaspitni stil nastavnika, oblici nastavnog rada, karakteristike same škole i sl. Nastojaćemo da ukažemo na pojedine specifičnosti datih faktora. 


\section{Karakteristike nastavnika i socioemocionalna klima u odeljenju}

Iako nastavnik nije jedini činilac koji utiče na stvaranje podsticajne odeljenske klime, nema sumnje da je njegov uticaj u tom pogledu od izuzetnog značaja (Avramović, 2010; Bognar i Matijević, 2005; Đermanov, i sar., 2016; Ilić, 2012; Krnjajić, 2007; Ševkušić, 2004). Od nastavnika se očekuje da stvara odeljensku klimu koja će doprineti ispoljavanju kreativnosti nastavnika i učenika, što se može postići ,samo u odgovarajućem socijalnom ambijentu, a to znači socijalnoj svesti (razumevanje tuđih misli, osećanja i namera), socijalnoj spretnosti (komunikacija na verbalnom i neverbalnom nivou, uspešno predstavljanje sebe) i pozitivnim socijalnim odnosima (uzajamno povezivanje i saradnja učenika i nastavnika)" (Avramović i Vujačić, 2010: 137).

Kako je ličnost nastavnika moguće razmatrati sa različitih aspekata, prema Krneti (1974), moguće je razlikovati psihološke (odnos prema samom sebi) i sociološke (odnos prema drugome) i pedagoške (odnos prema učeniku i vaspitnim vrednostima) dimenzije njegove ličnosti.

Realizovana su brojna istraživanja sa ciljem utvrđivanja poželjnih naspram nepoželjnih osobina nastavnika. U istraživanju koje je sproveo Laketa (1998) na uzorku od 594 učenika osnovnoškolskog uzrasta, došao je do podataka o osobinama nastavnika koje učenici visoko vrednuju: 1. Opšteljudske osobine: staloženost, smisao za humor, pravednost, nije ljut, iskrenost, pažljivost, dobrodušnost, ozbiljnost, inteligentnost, strogoća, ljubaznost, odlučnost, doslednost, lepo izgleda, lepo govori, poverljiv, itd.; 2. Pravičnost u vrednovanju rada učenika: pravednost u ocenjivanju, ne traži sitnice kada ocenjuje, blago ocenjuje, ohrabruje učenike dok odgovaraju, nagrađuje učenike, ne kažnjava slabim ocenama i ocenjuje javno. 3. Odnos prema učenicima: razume učenike, pomaže učenicima, sarađuje sa učenicima, ne viče na učenike, jednako se odnosi prema svim učenicima, ne primenjuje fizičke kazne, ceni i poštuje učenike, dobar je drug, ne ponižava učenike, dopušta da učenici iznose svoja mišljenja, prijatelj je sa učenicima, umereno je strog, voli učenike, poklanja pažnju slabim učenicima, zna da posavetuje, ne tera učenike sa časa, ima poverenja u učenike. 4. Radni kvaliteti: dobar predavač, voli i ceni rad, jasno izlaže, održava radnu disciplinu, podstiče učenike na rad i ohrabruje ih, zanimljivo izlaže, dobar je pedagog, itd.

U slučaju negativnih i nepoželjnih svojstava, učenici su u datom istraživanju istakli sledeće: 1. Opšteljudske osobine: nervoznost, drskost, strogoća, nekulturno ponašanje, nestrpljivost, preozbiljnost, prevelika popustljivost, nemarnost, samovolja, itd. 2. Pravičnost u vrednovanju rada učenika: nepravedno ocenjivanje, strogo ocenjivanje, traži sitnice, lako daje slabu ocenu, blag u ocenjivanju, mnogo traži za ocenu, prebrzo daje ocene, traži da se uči i nepotrebno, traži da se uči napamet $i$ teško daje dobru ocenu. 3. Odnos prema učenicima: viče na učenike, fizički ih kažnjava, ponižava ih, brzo se nervira, nije jednak prema svim učenicima, ne razume učenike, nedovoljno poklanja pažnju učenicima, nema poverenja u učenike, itd. 4. Radni kvaliteti: loš pedagog, ne voli da radi, misli da je njegov predmet glavni, ne 
sarađuje sa učenicima, čita iz knjige, slab predavač, ne poznaje gradivo, zadržava se na nevažnim stvarima, brzo predaje, traži apsolutnu poslušnost.

Pored poželjnih osobina ličnosti nastavnika, od važnosti je i način na koji nastavnik shvata suštinu svoje profesionalne delatnosti - da li kao duhovno ili emocionalno zadovoljstvo ili, pak, kao sredstvo za zadovoljenje materijalnih interesa i traženje finansijskih nagrada. Za stvaranje podsticajne socioemocionalne klime u odeljenju važno je da nastavnik prevashodno zauzima prvo stanovište. Iz tog razloga je prilikom nastojanja da se razume doprinos nastavnika stvaranju pozitivne socijalne klime u odeljenju potrebno imati u vidu i način na koji shvata svrhu svog rada (Avramović, 2010; Avramović i Vujačić, 2010).

Danas se sve više ukazuje na važnost potrebe za stalnim stručnim usavršavanjem nastavnika na mnogim područjima obrazovanja u cilju razvoja potrebnih kompetencija, čija je važna dimenzija i stvaranje podsticajnog okruženja za učenje. Od nastavnika se u tom pogledu očekuje: „da se permanentno profesionalno usavršava; da kritički preispituje vlasitu i uspešnu praksu drugih; da stvara podržavajuću klimu učenja i poučavanja; da razvija veštine saradnje i timskog rada kod sebe i svojih učenika; da razvija odnose podrške i umeće da zadrži i pruži kolegijalnu pomoć", ali i ,predanost i posvećenost u radu, otvorenost za promene u okruženju i angažovanje na efektivnom rešavanju uobičajenih i nepredviđenih situacija u praksi”" (Đermanov, i sar., 2016: 430).

Jurčić (2014) smatra da kompetencijski profil savremenog nastavnika uključuje dva nivoa. Prvi nivo karakterišu dimenzije pedagoške kompetencije, dok drugi dimenzije didaktičke kompetencije nastavnika. Savremeni nastavnik u svom radu trebalo bi da istovremeno radi na ostvarivanju vaspitne i obrazovne uloge škole. Dimenzije pedagoške kompetentnosti nastavnika su u vaspitno-obrazovnom procesu u interakciji sa dimenzijama didaktičke kompetentnosti. U okviru pedagoške kompetentnosti nastavnika moguće je razlikovati sledeće grupe kompetencija: personalne kompetencije (empatičnost, fleksibilnost, susretljivost, smirenost, pravednost itd.), komunikacijske kompetencije, analitičke kompetencije, socijalne kompetencije, emocionalne kompetencije, interkulturalne kompetencije, razvojne kompetencije, veštine u rešavanja problema. Didaktičke kompetencije nastavnika manifestuju se kroz: odabir i primenu metodologije izgradnje predmetnog kurikuluma, organizovanje i vođenje vaspitnoobrazovnog procesa, oblikovanje nastavne klime u odeljenju, utvrđivanje učenikovih postignuća u školi, kao i u pogledu razvoja modela vaspitnog partnerstva s roditeljima.

Svakako, važne kompetencije koje je potrebno razvijati - pored profesionalnih znanja, profesionalnih veština, sposobnosti i kognitivnih stilova, jesu i društveno prihvatljiv sistem vrednosti kod nastavnika, koji se odnosi na uvažavanje prava drugih, uvažavanje različitosti, brigu o dobrobiti učenika (Stanković, 2010), odgovarajuće percepcije, očekivanja, aspiracije, stavove, uverenja i sl. (Đermanov i Isak, 2016). Osim toga, trebalo bi imati u vidu da celokupno ponašanje nastavnika ispoljeno u načinu komunikacije sa učenicima, kojim bi trebalo da modeluje adekvatno socijalno ponašanje učenika, predstavlja posebno važan faktor (Lalić, 2005; Ševkušić, 2004).

Ipak, trebalo bi imati u vidu da efikasnost rada nastavnika u velikoj meri zavisi i od karakteristika učenika sa kojima rade. Specifičan sklop personalnih osobina 
koje doprinose pozitivnim ishodima u radu sa učenicima jednog uzrasta, ne mora nužno biti podjednako ili slično efikasan sa učenicima drugog uzrasta, imajući u vidu činjenicu da se učenici različitog urasta nalaze na drugačijim stadijumima intelektualnog, socijalnog i emocionalnog razvoja (Ševkušić, 2004).

Dalji faktor vezan za samog nastavnika koji je od posebnog značaja za stvaranje pozitivne odeljenske klime jeste način na koji rukovodi odeljenjem. U literaturi se najčešće ukazuje na razliku između sledeća tri vaspitna stila nastavnika, odnosno načina rukovođenja odeljenjem, koji doprinose uspostavljanju različitih tipova odnosa između nastavnika i učenika (Andrilović i Čudina, 1985; Avramović, 2010; Bratanić, 1990; Krnjajić, 2007; Laketa, 1998; Lalić, 2005):

(a) demokratski - koji odlikuje saradnja, određivanje ciljeva i definisanje načina njihovog ostvarivanja, zajedničko donošenje odluka, tolerancija, uvažavanje različitosti, razumevanje perspektive drugog, socijalna odgovornost, stimulisanje samoinicijativnosti, pomaganje učenicima sa zadovoljstvom, podsticanje grupne participacije, objektivno davanje pohvala i kritika;

(b) autoritarni - koji odlikuju sklonost ka izdavanju naredbi, ka jednostranom donošenju odluka od strane nastavnika, stroga disciplina, samovolja, pretnje, povišen ton;

(3) ravnodušni-koji je karakterističan po nemarnosti, nezainteresovanosti nastavnika za ponašanje i dobrobit učenika.

Jasno je da je za podsticanje pozitivne socioemocionalne klime u odeljenju važan demokratski vaspitni stil nastavnika, na koji učenici najčešće reaguju tako što pokazuju želju i volju za međusobni rad i rad sa nastavnikom, međusobno se podržavaju i preuzimaju odgovornost za svoje školske obaveze, prisutna je visoka motivacija za učenje i školsko postignuće. Uobičajene reakcije učenika na autoritarni vaspitni stil jesu: pokornost, nenaklonost prema nastavniku, nezainteresovanost $\mathrm{i}$ nespremnost na saradnju, dok na ravnodušni vaspitni stil učenici najčešće reaguju pasivnim odnosom prema školskim obavezama, smanjenom koncentracijom, nervozom i iritiranošću, nespremnošću za saradnju i grupni rad. Ipak, efekat primene pojedinog vaspitnog stila zavisiće i od samih učenika sa kojima radi. Primećeno je da psihološki različiti tipovi učenika imaju različite reakcije na obrasce ponašanja istog nastavnika (Krnjajić, 2007).

U literaturi se, osim razlikovanja demokratskog, autoritativnog i indiferentnog vaspitnog stila, ukazuje na razliku između dominantnog naspram integrativnog ponašanja nastavnika (Bognar i Matijević, 2005), kao i između direktivnog i nedirektivnog odnosa nastavnika prema učenicima (Avramović, 2010; Bognar i Matijević, 2005; Lalić, 2005). Kako navodi Krnjajić (2007), date konstrukte najvećim delom može smatrati istoznačnim.

Nastavnikovo rukovođenje odeljenjem biće neuporedivo uspešnije ukoliko dobro poznavanje svoj posao, ukoliko ga zasniva na objektivnim zakonitostima ustrojstva nastavnog procesa, ukoliko su mu jasni ciljevi i zadaci škole u kojoj radi i nastave u njoj, kao i ukoliko dobro poznaje psihofizičke karakteristike učenika sa kojima radi (Krneta, 1974). Osim toga, potrebno je imati u vidu da nastavnik kao kreator odeljenske klime zauzima različite uloge u toku sopstvenog profesionalnog 
razvoja, odnosno u tom procesu prolazi kroz određene faze profesionalnog razvoja. U prvoj fazi razvoja usmeren je na sebe, na sopstveno snalaženje u interakciji sa učenicima. Drugu fazu karakteriše pomeranje brige na upravljanje, na primenu nastavnih i vaspitnih metoda, dok treću fazu odlikuje usmerenost na ishode ili rezultate učenja (Ševkušić, 2004).

\section{Odnosi između nastavnika i učenika, učenika međusobno, školski faktori i socioemocionalna klima u odeljenju}

Za razumevanje prirode socioemocionalne klime u odeljenju, pored sagledavanja uloge nastavnika doprinosu stvaranja pozitivne klime, potrebno je sagledati i ulogu učenika u tom procesu. Odnosno, smatra se da nastavnik nije jedini akter koji doprinosi pozitivnoj odeljenskoj klimi, već da je taj fenomen potrebno razmotriti i sa aspekta doprinosa i drugih faktora (Krneta, 1974).

Smatra se da postoji značajna povezanost između ponašanja nastavnika i ponašanja učenika i da, shodno tome, od kvaliteta i intenziteta uspostavljenih međusobnih odnosa zavisi i socioemocionalna klima u odeljenju (Lalić, 2005). Pored akademskih koristi, pozitivan odnos sa nastavnikom povezan je i sa razvojem mnogih ličnih kompetencija koje doprinose uspehu u školskom učenju. Pokazalo se da učenici u odeljenjima sa pozitivnom socioemocionalnom klimom provode više vremena u interakciji sa nastavnikom i dobijaju više individualne podrške od strane nastavnika. Učenikov doživljaj brižnog interpersonalnog odnosa sa nastavnikom i vršnjacima iz odeljenja bazira se na uvažavajućim i kooperativnim odnosima koji imaju pozitivan uticaj na akademsko i interpersonalno ponašanje, kao i na stavove prema školi i motivaciju učenika (Krnjajić, 2007).

Pored toga, potrebno je imati u vidu da nastavnik u interakciji sa učenicima $u$ odeljenju nastoji da razume razloge koji su u osnovi određenog ponašanja učenika. Kada nastavnik sebi zada cilj uspostavljanja određene socijalne klime u odeljenju nastojaće da u tu svrhu upotrebi određena sredstva, kao što su pravno-normativna sredstva, moralne konvencije, ali i razumevanje učeničkog ponašanja. Takvo razumevanje je, u suštini, subjektivnog karaktera, jer se zasniva na nastavnikovim prethodnim iskustvima, profesionalnim saznanjima i sl. Ipak, nastojanje nastavnika da otkrije moguće značenje učenikovog ponašanja karakterišu izvesne slabosti - činjenica da ni učenici sami ponekad nisu svesni stvarnog značenja sopstvenog ponašanja, kao i da manifestni oblici sličnog ponašanja kod učenika često imaju različito značenje za različite učenike (Avramović, 2010; Avramović i Vujačić, 2010).

S druge strane, i učenici nastoje da svesno ili nesvesno otkriju osnovne motive ponašanja nastavika, ali to čine sa znatno manje iskustva i, prevashodno, vođeni intuicijom (Avramović, 2010; Avramović i Vujačić, 2010). Ukoliko osete da nastavnik nije u stanju da uspešno vlada situacijom u odeljenju, nastojaće da se ponašaju na sebi svojstven način. Ukoliko učestalo kasni, takvo ponašanje nastavnika učenicima šalje poruku da i oni sami mogu na takav način da se odnose prema vremenu, kao jednom od resursa nastave. Suprotno, kada nastavnik jasno definiše značenja svog 
ponašanja, učenici će uglavnom usklađivati sopstvena ponašanja sa njegovim (Avramović i Vujačić, 2010).

Na stvaranje klime u odeljenju, pored nastavnika, značajnog uticaja imaju i sami učenici. Pozitivna klima u odeljenju ne može da se stvori ukoliko ne postoji vaspitni odnos nastavnika i učenika prema moći, pri čemu nastavnik koristi moć u odeljenju kao deo socijalnog odnosa, a istovremeno i kao prenosilac znanja iz određenog predmeta. Moć je sredstvo upravljanja socijalnim procesima u odeljenju. Klima u odeljenju ne može se stvoriti ukoliko ne postoji određeni odnos nastavnika i učenika prema moći. U tom pogledu, u cilju valjanog kontrolisanja ponašanja učenika, za nastavnika je od izuzetne važnosti da donese dobre odluke u pogledu upravljanja odeljenjem i da ih efikasno sprovede. Ako želi da bude uspešan u stvaranju pozitivne socijalne atmosfere, nastavnik mora da obrati pažnju na sledeće procese: donošenje odluka, rešavanje sukoba, upotrebu moći u odeljenju i način upravljanja. U protivnom, učenici će biti u prilici da stvore klimu kakva odgovara njima, a ne nastavniku. Odnosno, važan uslov za stvaranje povoljne socijalne klime u odeljenju je odnos poštovanja i poverenja između nastavnika i učenika, tj. racionalan odnos prema moći. U pitanju je nastavnikova sposobnost da shvati potrebe, probleme i težnje učenika i da uskladi njihovo međusobno ponašanje, imajući u vidu da različiti učenici u vaspitno-obrazovnom procesu ispoljavaju različite motive, stavove, crte ličnosti, vrednosti, interese (Avramović, 2010; Avramović i Vujačić, 2010).

U tom kontekstu, osim prirode odnosa između nastavnika i učenika, potrebno je razmotiriti i uticaj drugih značajnih faktora poput stepena agresivnosti među učenicima i drugih problema u ponašanju u grupi dece. Takvi faktori mogu imati negativne efekte po odeljensku klimu, uprkos adekvatnom nastojanju nastavnika da uspostavi pozitivnu klimu u odeljenju (Bognar i Matijević, 2005; Lalić, 2005).

Kao još jedna prepreka radu nastavnika na stvaranju podsticajne odeljenske klime svakako je i neformalno grupisanje učenika u odeljenju. Stoga bi nastavnik trebalo da posebnu pažnju posveti utvrđivanju i proučavanju sastava i sistem socijalnih odnosa koji se uspostavljaju u odeljenju. Takva grupisanja mogu nepovoljno uticati na odnos između nastavnika i učenika na nivou odeljenja, jer su ponašanje i stavovi pojedinačnog učenika uslovljeni ponašanjem vršnjaka iz neformalne grupe kojoj pripada. U tom pogledu, moguće je razlikovati sledeće tri uloge učenika i grupa u stvaranju određene odeljenske klime: a) konstruktivnu, koju odlikuje saradnja, pažnja i sl., b) destruktivnu, koju odlikuje omalovažavanje nastavnika, uvredljivi nastupi i sl., i c) opstruktivnu, karakterističnu po učestalosti bežanja sa časa, izbegavanju školskih aktivnosti i sl. (Avramović, 2010; Avramović i Vujačić, 2010).

Na kvalitet socioemocionalne klime u odeljenju, pored navedenih, imaju uticaja i drugi faktori poput: veličine odeljenja, organizacije odeljenja i prethodnih iskustava učenika (Krnjajić, 2007). Veličina odeljenja u značajnoj meri utiče na kvalitet odeljenske socioemocionalne klime. U odeljenjima sa većim brojem učenika prilike za individualnu participaciju učenika su u priličnoj meri smanjene, ali će efekat veličine odeljenja varirati u zavisnosti od vrste primenjenih nastavnih metoda, uzrasta učenika i karakteristika nastavnika koji sa njima rade. Organizacija odeljenja uticaće na učestalost interakcije među učenicima, pri čemu fleksibilna organizacija u pogledu prostora, vremena, uzrasta, ličnog izbora i sl., doprinosi uspostavljanju povoljnije odeljenske 
klime. Prethodna iskustva učenika mogu biti ograničavajući faktor kod onih učenika koji su se prvobitno dobro adaptirali na autokratski tip nastavnikovog vođenja u situacijama kada su očekivanja i zahtevi u tom pogledu promenjeni. Pored načina vođenja, i prethodno drugačije iskustvo u pogledu načina vrednovanja učeničkih aktivnosti (npr. insistiranje na usvajanju i reprodukovanju činjenica), takođe, može imati nepovoljan uticaj na njihovo kasnije ponašanje u izmenjenim okolnostima.

Svakako, i klima na nivou škole može imati povoljan ili nepovoljan uticaj na odeljensku klimu i ponašanje učenika. Pokazalo se da je pozitivno ponašanje učenika prisutno u školama koje se doživljavaju kao bezbedna sredina, čiji je direktor energičan, vredan i odgovoran lider, u kojima su školska pravila jasna, pravedna i dosledno primenjivana, u kojima su učenici ponosni na svoju školu, i u kojima se od učenika očekuju visoka školska postignuća (Haynes, et al., 1997, prema Krnjajić, 2007: 48).

\section{Primena različitih oblika nastavnog rada u cilju podsticanja pozitivne odeljenske klime}

Pri razmatranju problema stvaranja podsticajne socioemocionalne klime u odeljenju potrebno je imati u vidu i karakteristike nastavnog rada na času (Krnjajić, 2007; Lalić, 2005). Pokazalo se da različito strukturirane situacije učenja imaju različite implikacije za interpersonalne odnose učenika i razvoj učeničkih socijalnih kompetencija (Lalić, 2005; Ševkušić, 2004). Smatra se da strukturiranje nastave uz korišćenje malih subgrupa unutar odeljenja daje pozitivne rezultate, ne samo zbog individualnih razlika, već i zbog omogućavanja maksimalne participacije svim učenicima u nastavnim aktivnostima (Krnjajić, 2007).

Od posebnog značaja za stvaranje pozitivne socioemocionalne klime u odeljenju je stvaranje prilika za tzv. kooperativno učenje (Bognar i Matijević, 2005; Krnjajić, 2002, 2007; Lalić, 2005). Pokazalo se da kooperativne vršnjačke interakcije doprinose da se kod učenika razviju otvoreni, pošteni, prijateljski odnosi i spremnost da se pomogne drugome (Bognar i Matijević, 2005), pozitivna međuzavisnost ciljeva, uzajamna naklonost i poštovanje, spremnost da se sasluša tuđe mišljenje i osećanje odgovornosti prema drugima (Ševkušić, 2004). Takvo strukturiranje nastave podrazumeva i promenu pozicije nastavnika u vaspitno-obrazovnom procesu, koji bi iz uloge predavača trebalo da se preorijentiše na ulogu onoga ko olakšava grupne procese, uspostavlja grupni cilj i kriterijume procene grupnog postignuća (Ševkušić, 2004).

Dalje, uključivanje učenika u odeljensku i/ili grupnu diskusiju je, takođe, važna komponenta efikasne nastave i smatra se značajnim iskustvom za same učenike, koje zauzvrat doprinosi stvaranju podsticajne socioemocionalne klime u odeljenju (Krnjajić, 2007; Lalić, 2005). Bitne pretpostavke efektivne grupne diskusije jesu osposobljavanje učenika za preuzimanje vođstva, sleđenje vođe i prihvatanje odgovornosti za sopstvene radne uloge, uz prethodno zadovoljene intelektualne potrebe i rešene socioemocionalne tenzije kod nastavnika i učenika. 


\section{Uticaj odeljenske socioemocionalne klime na adaptaciju na školu i školsko postignuće učenika}

Pokazalo se da postoji značajna povezanost između odnosa nastavnik-učenik i učenikove socijalne i akademske prilagođenosti u školi (Krnjajić, 2007; Lalić, 2005). Način na koji školsko odeljenje funkcioniše, način na koji učenici ostvaruju socijalne interakcije i nastavnikova uloga u tim aktivnostima imaju izuzetan značaj za uspešnu realizaciju procesa nastave i učenja. Socioemocionalna klima u odeljenju jedna je od primarnih determinanti ne samo kvaliteta i kvantiteta usvojenog znanja, već i načina na koji učenici reaguju na školske aktivnosti i stavove koje imaju prema školi. Ispoljavanje brige, međusobnog poštovanja i fizička bliskost između nastavnika i učenika, kao i među učenicima predstavljaju kvalitete koji doprinose razvoju osećanja sigurnosti kod učenika, povećanju nivoa akademskog postignuća i formiraju pozitivnih stavova prema školi (Krnjajić, 2007). Efekti percipiranja odeljenske klime prevashodno se ogledaju u poželjnom ponašanju i stavovima učenika, postizanju školskog uspeha, većoj motivisanosti za učenje i saznavanje, aktivnom učešću u procesu nastave, razvoju pozitivne slike o sebi, uverenosti u sopstvene akademske kompetencije i sl. S druge strane, takva klima povratno povoljno utiče i na efikasnost i kreativnost u vaspitno-obrazovnom radu nastavnika (Đermanov, i sar., 2016). Nasuprot tome, socioemocionalna odeljenska klima koju odlikuje visok nivo nepoverenja i nepoštovanja među učenicima i između nastavnika i učenika najčešće rezultira nižim obrazovnim ishodima (Krnjajić, 2007).

Rezultati brojnih istraživanja ukazuju na značaj koji socioemocionalna klima u odeljenju i adekvatni nastavnik-učenik odnosi imaju za akademski uspeh učenika. Primera radi, rezultati empirijskog istraživanja koje su sproveli Rucinski, Braun i Dauner (Rucinski, et al., 2018) na uzorku od 526 učenika i njihovih 35 nastavnika pokazuju da je kvalitet nastavnik-učenik odnosa povezan sa boljom psihosocijalnom adaptacijom učenika na školski kontekst, ali i da povoljna školska klima može umanjiti rizik od agresivnog ponašanja kod učenika koji nisu uspostavili adekvatan odnos sa nastavnikom. Pokazalo se da je negativna školska klima, okarakterisana učestalim konfliktima, povezana sa većom učestalošću agresivnog ponašanja i nižim školskim postignućem. Međutim, pokazalo se da emocionalna podrška na nivou odeljenja, karakteristična za povoljnu odeljensku klimu, ne može kompenzovati loše dijadične odnose između nastavnika i učenika.

U jednom drugom istraživanju (Ponitz et al., 2009), pak, u kome je proučavana adaptacija učenika u početnim razredima školovanja, ustanovljeno je da su učenici u dobro organizovanim odeljenjima imali bolja postignuća u oblasti opismenjavanja, nego oni iz slabije organizovanih i haotičnih odeljenja. Ustanovljene su izvesne razlike u pogledu pola učenika, pri čemu se pokazalo da su dečaci u haotičnim odeljenjima imali bolja postignuća u oblasti matematike u dobro organizovanim odeljenjima u poređenju sa devojčicama, kod kojih takva povezanost nije utvrđena.

I rezultati drugih istraživanja potvrđuju nalaze o pozitivnoj povezanosti između povoljne odeljenske klime i bolje psihosocijalne adaptacije učenika na početku školovanja (npr. Buyse et al., 2009), kao i o povezanosti socijalne klime u odeljenju i obrazovnih ishoda učenika (npr. Anderson, 1970). 


\section{Zaključak}

Nastavnik je veoma važan, ali ne i jedini činilac koji doprinosi stvaranju podsticajne socioemocionalne klime u odeljenju. Pored osobina nastavnika, njegovog načina vođenja i modelovanja ponašanja u različitim situacijama, bavljenja dečjim konfliktima i drugim vaspitnim problemima, na stvaranje podsticajne klime u odeljenju svojevrstan uticaj imaju i osobine učenika, odnosi između nastavnika i učenika, odnosi između učenika, nastavnikovo razumevanje ponašanja učenika, oblici nastavnog rada, karakteristike same škole i sl. U nastojanju da se doprinese poboljšanju vaspitno-obrazovne prakse u konkretnoj školi potrebno je razmotriti i karakteristike datih faktora.

\section{Literatura}

Anderson, J. G. (1970). Effects of Classroom Social Climate on Individual Learning. American Educational Research Journal, 7(2), 135-152.

Andrilović, V. i M. Čudina (1985). Psihologija učenja i nastave. Zagreb: Školska knjiga.

Avramović, Z. (2010). Problem stvaranja socijalne klime u odeljenju. Pedagogija, 1(10), 104-117.

Avramović, Z i Vujačić, M. (2010). Nastavnik između teorije i nastavne prakse. Beograd: Institut za pedagoška istraživanja.

Bogner, L. i M. Matijević (2005). Didaktika. Zagreb: Školska knjiga.

Bratanić, M. (1990). Mikropedagogija - Interakcijsko-komunikacijski aspekti odgoja. Zagreb: Školska knjiga.

Buyse, E., Verschueren, K., Verachtert, P. and Van Damme, J. (2009). Predicting School Adjustment in Early Elementary School: Impact of Teacher-Child Relationship Quality and Relational Classroom Climate. The Elementary School Journal, 110(2), 119-141.

Đermanov, J. i Isak, D. (2016). Razredna klima u osnovnoj školi: percepcije i očekivanja učenika. Pedagoška stvarnost, 62(1), 61-78.

Đermanov, J., Kosanović, M. i Isak, D. (2016). Razredna klima kao novo područje pedagoškog savetovanja nastavnika. Pedagoška stvarnost, 62(3), 419-436.

Havelka, N. (2000). Učenik i nastavnik u obrazovnom procesu. Beograd: Zavod za udžbenike i nastavna sredstva.

Ilić, I. (2012). Što je zaista važno u odnosu nastavnika i učenika. U: Upravljanje razredom (2-20). Zagreb: Agencija za strukovno obrazovanje i obrazovanje odraslih u saradnji sa British Councilom.

Jelavić, F. (2008): Didaktika. Jastrebarsko: Naklada Slap.

Jurčić, M. (2014). Kompetentnost nastavnika - pedagoške i didaktičke dimenzije. Pedagogijska istraživanja, 11(1), 77-93.

Krneta, Lj. (1974). Pedagogija. Beograd: Naučna knjiga.

Krnjajić, S. (2002). Socijalni odnosi i obrazovanje. Beograd: Institut za pedagoška istraživanja. 
Krnjajić, S. (2007). Pogled u razred. Beograd: Institut za pedagoška istraživanja.

Laketa, N. (1998). Učitelj-nastavnik-učenik. Užice: Učiteljski fakultet.

Lalić, N. (2005). Nastavnik kao kreator klime u odeljenju. U: S. Joksimović (ur.). Vaspitanje mladih za demokratiju (str. 183-203). Beograd: Institut za pedagoška istraživanja.

Ponitz, C. C., Rimm-Kaufman, E. S., Brock, L. L. and Nathanson, L. (2009). Early Adjustment, Gender Differences, and Classroom Organizational Climate in First Grade. The Elementary School Journal, 110(2), 142-162.

Rucinski, L. C., Brown, L. J. and Downer, T. J. (2018). Teacher-Child Relationships, Classroom Climate, and Children's Social-Emotional and Academic Development. Journal of Educational Psychology, 110(7), 992-1004.

Stanković, D. (2010). Mesto kompetencija u profesionalnom razvoju nastavnika. U: N. Polovina i J. Pavlović (ur.). Teorija i praksa profesionalnog razvoja nastavnika (str. 63-82). Beograd: Institut za pedagoška istraživanja.

Ševkušić, S. (2004). Nastavnik i socijalno ponašanje učenika. U: S. Krnjajić (ur.). Socijalno ponašanje učenika (str. 129-150). Beograd: Institut za pedagoška istraživanja.

\title{
THE ROLE OF TEACHERS IN THE CREATION OF POSITIVE CLASSROOM CLIMATE
}

\author{
Marija Marković \\ University of Nis, Faculty of Philosopy, Department for Pedagogy
}

\begin{abstract}
Teaching profession in modern schools implies an endeavor to achieve numerous roles that are quite different and complex. In addition to achieving educational tasks, contemporary teachers are expected to devote special attention to the upbringing aspect of working with students. Classroom context and the socio-emotional climate in it represent an important institutional context which is significantly influenced by the teacher itself. Classroom climate is significantly influenced by the individual characteristics of teachers and students, the teaching style of the teacher, the position of pupils in the teaching process, the quality of interpersonal relationships, and other factors. The paper identifies different meanings of terms used to indicate the classroom climate, as well as the characteristics of the positive and negative classroom climate. The teacher's qualities, the teaching styles of teachers, the relationships between teachers and students, the relationships between students, as well as their relationship with the classroom climate are discussed. We points to the interconnections which may exist between certain characteristics of classroom climate and school achievement of students. In the end, we points to the importance of consideration the given factors in a practical effort to establish a positive classroom climate.
\end{abstract}

Keywords: classroom climate, teacher, students, academic achievement, classroom context

Citiranje članka:

Marković, M. (2018). Uloga nastavnika u stvaranju pozitivne klime u odeljenju. Godišnjak za pedagogiju, 3(2), 45-56 